\title{
REVIEW KONSEP RESPONSIVE DESIGN DENGAN FRAMEWORK MATERIALIZE PADA WEBSITE
}

\author{
Cindy Novianty \\ Jurusan Teknik Informatika dan Komputer, Politeknik Negeri Jakarta \\ Jl. Prof.Dr.G.A.Siwabessy, Kampus UI, Depok, Telp: 021-7863534 \\ e-mail: cindynovianty98@gmail.com
}

\begin{abstract}
Abstrak-Responsive web design merupakan sebuah desain website yang dapat menyesuaikan tiap ukuran pada tiap device. Berdasarkan hasil dari beberapa responden menyatakan $62 \%$ responden setuju jika beberapa website yang belum mampu menyesuaikan ukuran tampilan web, 54\% responden setuju bahwa desain yang responsive mempengaruhi faktor kenyamanan responden, $60 \%$ responden setuju bahwa konten utama dan fungsionalitas dari website yang sulit diakses melalui perangkat mobile, $56 \%$ responden setuju bahwa tampilan website yang kurang responsive berpengaruh buruk terhadap faktor kenyamanan responden, $52 \%$ responden setuju bahwa website yang belum mampu menyesuaikan ukuran pada tiap perangkat mobile. Dari hasil review tersebut dapat disimpulkan bahwa website yang tidak responsive mempengaruhi ketidak nyamanan para pengguna untuk mengakses informasi melalui website online.
\end{abstract}

Keywords-responsive design, website online, mobile, responden, review

\section{PENDAHULUAN}

Teknologi informasi saat ini berkembang dengan pesat di berbagai bidang kehidupan manusia, Maraknya penggunaan website online disebabkan pula oleh jumlah pengguna internet yang terus bertumbuh pesat. Ini merupakan tantangan baru bagi para developer dalam hal meningkatkan kualitas website yang menyajikan informasi yang cepat, tepat, friendly dan mudah dijangkau oleh seluruh lapisan masyarakat serta dapat diakses oleh berbagai media dan berbagai flatform.

Hal ini didukung oleh perkembangan mobile device yang semakin meningkat dari tiap tahunnya, terutama penggunaan tablet dan smartphone. Menurut hasil survei Asosiasi Penyelenggara Jaringan Internet Indonesia (APJII) tahun 2016 mengungkapkan bahwa 63,1 juta orang atau 47,6 persen mengakses dari smartphone dan 2,2 juta orang atau 1,7 persen mengakses hanya dari komputer. Hal tersebut, mendorong para developer untuk me-ningkatkan kualitas website yang responsive atau mobile-friendly. Akan tetapi, perbedaan ukuran pada tiap device merupakan salah satu factor ketidak nyaman bagi para pengguna. Penggunaan mobile device yang semakin meningkat mengharuskan para developer dalam menciptakan website yang nyaman dan responsive.

Responsive web design merupakan sebuah desain website yang dapat menyesuaikan tiap ukuran pada tiap device. Penerapan responsive design ini di kombinasikan pada flexible grids, javascript, CSS media queries dan HTML. Manfaat dari responsive web design yaitu sebuah website yang dapat beradaptasi pada tata letak ukuran device dengan ukuran font,gambar dan komponen lainnya tanpa harus melakukan horizontal scrolling.

\section{TINJAUAN PUSTAKA}

A. Web

Web merupakan kumpulan dokumen- dokumen yang tersebar di mesin-mesin di internet. Dokumen ini biasa disebut page (halaman HTML). Tiap page mengandung link ke page yang lain di mesin yang lain di internet. Halaman web yang melakukan point ke halaman yang lain ini dinamakan menggunakan Hypertext. String yang melakukan link ke halaman yang lain disebut dengan Hyperlink. (Tabratas Tharom, Marta Dinata dan Xerandy, dalam Bertha, 2001:64).

\section{B. Fixed Width Design}

Fixed-width design (FWD) diterapkan pada website dengan fixed website layout yang memiliki wrapper dengan lebar yang fixed (tetap), dan komponen yang terdapat didalamnya memiliki baik itu lebar yang ditentukan dengan persentase tertentu atau lebar yang tetap. Hal yang terpenting adalah bahwa elemen wrapper diatur untuk tidak dapat bergerak. Tidak dipedulikan, berapapun resolusi layar yang pengunjung website gunakan, pengunjung akan melihat lebar website yang sama dengan pengunjung yang lain. (Knight, K, 2009). 


\section{Responsive Design}

Menurut Noah Daniels (2004) Responsive Design adalah sebuah pembangunan website dengan menampilkan design yang elegan dengan ukuran yang sesuai pada tiap device yang ditampikan. Dengan adanya responsive design, hanya memiliki satu website namun bisa diakses oleh berbagai device dengan ukuran layar berbeda-beda, memberikan kemudahan dalam maintenance dan hanya dibutuhkan satu alamat domain bagi keseluruhan.

Berdasarkan artikel UIE yang berjudul

"Device Experience \& Responsive Design", responsive design merupakan salah satu teknik yang dapat membuat proses perancangan aplikasi dan situs web untuk berbagai jenis perangkat menjadi lebih mudah. Hal ini dikarenakan bahwa dengan menggunakan responsive design, perancang dimungkinkan untuk dapat menerapkan solusi bagi berbagai resolusi layar, density, dan rasio aspek pada banyak jenis perangkat. Responsive design memiliki kemampuan untuk mengelola aset media dengan efektif. Hal ini memberikannya keunggulan untuk dapat diterapkan ke dalam perancangan situs web sehingga situs dapat diakses melalui smartphone, tablet, desktop, ataupun smart $T V$ tanpa memperlihatkan perbedaan yang terlalu besar dalam hal penggunaan.

Berdasarkan dari kedua pengertian diatas bahwa Responsive Design adalah sebuah pembangunan website dengan menampilkan design yang elegan dengan ukuran yang sesuai pada tiap device untuk dapat menerapkan solusi bagi berbagai resolusi layar, density, dan rasio aspek pada banyak jenis perangkat yang dapat diakses melalui smartphone, tablet, desktop, ataupun smart TV tanpa memperlihatkan perbedaan yang terlalu besar dalam hal penggunaan.

\section{Materialize}

Materialize adalah sebuah framework intuitif yang mirip dengan Bootstrap dan foundation yang menawarkan komponen UI. Namun, berbeda fungsi karena Bootstrap dan Foundation berbasis mobile pertama kali sedangkan Materialize mengikuti filosofi Material Design dari Google. (Anirudh Prabhu dan Aravind Shenoy, 2016).

\section{E. CSS}

CSS atau Cascading Style Sheet. CSS pertama kali diusulkan olhe Hakon Wium Lie tahun 1994 dan selanjutnya distandarisasi oleh W3C. CSS memberikan cara yang mudah dan efisien bagi pemrogram untuk menentukan tata letak halaman web dan mempercantik halaman dengan elemen desain seperti warna, sudut bulat, gradien, dan animasi. seperti halnya HTML, versi CSS juga berkembang. Versi pertama yang ditetakan oleh W3C adalah CSS 1 (dibaca CSS Level 1) pada bulan Desember 1996. Selanjutnya berkembang menjadi CSS 2 (ditetapkan bulan Mei 1998). CSS 2.1 (tahun 2011) dan CSS 3 yang diusulkan pada bulan 2012 . Versi yang sedang populer saat ini adalah CSS 3 yang memiliki banyak kelebihan disbanding versi sebelumnya seperti penambahan fitur media-queries dan penanganan font web. (Achmad Solichin, 2013).

\section{F. HTML}

HTML merupakan singkatan dari Hypertext Markup Language. HTML dikembangkan pertama kali oleh Tim Berners-Lee Bersamaan dengan protokol HTTP (Hypertext Transfer Protocol) pada tahun 1989. HTML merupakan bahasa pemrograman web yang memberitahukan peramban web (web browser) bagaimana menyusun dan menyajikan konten di halaman web. Dengan kata lain HTML adalah pondasi web. (Achmad Solichin, 2013).

\section{G. Javascript}

Pertama kali Javascript dikembangkan oleh Netscape dengan nama awal LiveScript. Fungsi utama dari Javascript adalah untuk menambah fungsionalitas dan kenyamanan halaman web. Javascript lebih fokus pada proses pengolahan data di sisi client serta menyajikan komponen web yang lebih interaktif. Javascript makin populer sejak kemunculan konsep AJAX (Asynchronous Javascript and $X M L$ ) yang memungkinkan interaksi antara client dan server lebih elegan dan fleksibel. (Achmad Solichin, 2013).

\section{H. Jquery}

Jquery adalah library atau kumpulan kode Javascript siap pakai. Keunggulan menggunakan jquery dibandingkan dengan Javascript standar, yaitu menyederhanakan kode Javascript dengan cara memanggil fungsi-fungsi yang disediakan oleh jquery. Javascript sendiri merupakan bahasa scripting yang bekerja di sisi client/browser sehingga website bisa lebih interaktif. Jquery pertama kali dirilis tahun 2006 oleh John Resig. Jquery menjadi sangat populer hingga telah digunakan pada banyak website termasuk website kelas dunia seperti Google, Amazon, Twitter, ESPN, dan lain-lain. (Aloysius Sigit W, 2011). 


\section{C\# Programming}

C\# (dibaca: C sharp) merupakan pemrograman berorientasi objek yang dikembangkan terutama oleh Anders Heljsberg, arsitek kepala di Microsoft dan seorang insinyur yang hebat. C\# telah diterima sebagai standar aplikasi Web dan layanan Web berbasis XML. (Shelly Cashman Vermaat, 2016).

\section{J. Media Queries}

Media queries merupakan sebuah teknik CSS yang dapat menentukan atau mengatur tampilan tiap device berdasarkan resolusinya. Hal tersebut diperlukan untuk menentukan ukuran tiap font, gambar pada tiap resolusi device yang dapat memudahkan para pengguna dalam hal mencari info dari website secara dinamis dan efektif.

\section{HASIL DAN PEMBAHASAN}

Berdasarkan hasil pengamatan dari beberapa sumber menyatakan bahwa :

- $62 \%$ responden setuju jika beberapa website yang belum mampu menyesuaikan ukuran tampilan web seperti header, footer, gambar maupun font teks merupakan hal yang berpengaruh pada kenyamanan responden saat mengakses web melalui perangkat mobile

- $54 \%$ responden setuju bahwa desain yang responsive mempengaruhi faktor kenyamanan responden dalam hal membaca teks, menu maupun gambar.

- $\quad 60 \%$ responden setuju bahwa konten utama dan fungsionalitas dari website yang sulit diakses melalui perangkat mobile mempengaruhi faktor kenyamanan responden.

- $56 \%$ responden setuju bahwa halaman atau tampilan website yang kurang responsive atau tidak fokus berpengaruh buruk terhadap faktor kenyamanan responden.

- $52 \%$ responden setuju bahwa website yang belum mampu menyesuaikan ukuran pada tiap perangkat mobile mempengaruhi aktivitas responden saat mengakses website tersebut.

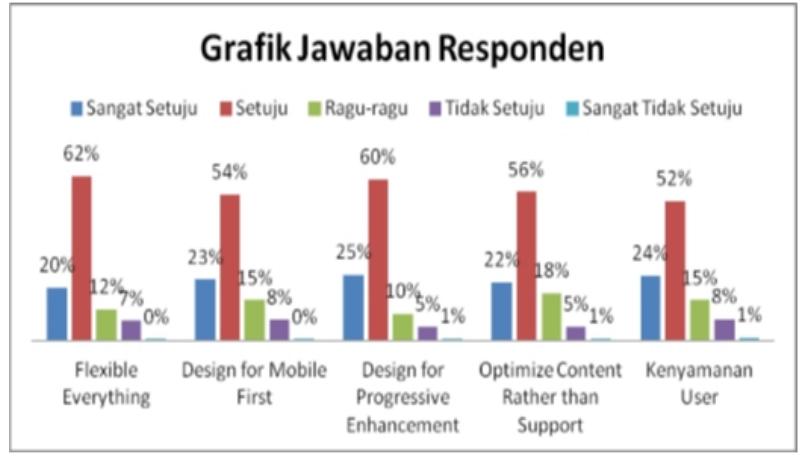

Gbr 1. Grafik Jawaban Responden (Mohammmad Fariz Ikhsan, et al, 2014)

Hasil dari gambar di atas menunjukkan bahwa saat pengguna mengakses website di perangkat mobile dengan tampilan yang tidak fokus atau versi desktop maka kenyamanan pengguna akan berkurang saat mengakses website tersebut.

Keuntungan penggunaan website dengan konsep responsive design yaitu:

- Memberi kenyamanan bagi para pengguna pada saat mengakses website melalui perangkat mobile

- Mencegah terjadinya horizontal scrolling pada saat pengguna mengakses web melalui perangkat mobile.

- Hanya pemakaian satu alamat domain, website tersebut bisa diakses ke semua perangkat seperti tab, smartphone, notebook, komputer.

- Dapat menyesuaikan ukuran atau tampilan website pada tiap perangkat yang di akses.

- Kemudahan dalam maintenance merupakan sebuah keuntungan bagi owner atau perusahaan tersebut.

\section{KESIMPULAN}

Berdasarkan kesimpulan dari hasil review di atas bahwa:

1. Berdasarkan hasil dari beberapa responden menyatakan $62 \%$ responden setuju jika beberapa website yang belum mampu menyesuaikan ukuran tampilan web, 54\% responden setuju bahwa desain yang responsive mempengaruhi faktor kenyamanan responden, $60 \%$ responden setuju bahwa konten utama dan fungsionalitas dari website yang sulit diakses melalui perangkat mobile, $56 \%$ responden setuju bahwa tampilan website yang kurang responsive berpengaruh buruk terhadap faktor kenyamanan responden, $52 \%$ responden setuju bahwa website yang belum mampu menyesuaikan ukuran pada tiap perangkat mobile. 
2. Berdasarkan hasil responden di atas menyatakan ketidak nyamanan pengguna pada saat mengakses website yang belum mampu menyesuaikan tampilan pada tiap device, mempengaruhi kenyamanan para pengguna.

3. Keuntungan dari responsive design salah satunya menghindari terjadi horizontal scrolling pada saat mengkases website melalui perangkat mobile serta ukuran website yang dapat menyesuaikan tampilan pada tiap resolusi layar.

\section{DAFTAR PUSTAKA}

[1] Anugerah, S.2013, "Pemodelan Responsive Web Menggunakan Foundation Framework Dalam Pengembangan Perangkat Lunak Berbasis Perangkat Bergerak". Seminar Nasional Informatika 2013. [15 Maret 2017].

[2] Daniels, N. 2014. Responsive Design Road Map. Munich: BookRix Gmbh

[3] Hidayat, A, et al. 2016. "Penerapan Responsive Web Design Dalam Perancangan Sistem Modul Online Adaptif". Journal of Information System. 12(1). 15.http://jsi.cs.ui.ac.id/ index.php/jsi/article/view/435[15 Maret 2017].

[4] Ikhsan, M.F, et al. "Analisis User Interface Pada Mobile Device Menggunakan Heuristics of Responsive Web Design”. pp 18.https://www.google.com/url?sa $=$ t\&rct $=\mathrm{j} \& \mathrm{q}=\&$ esrc $=\mathrm{s}$ $\&$ source $=$ web $\& \mathrm{~cd}=1 \& \mathrm{cad}=$ rja\&uact $=8 \& \mathrm{ved}=0$ ahUKE wjAsvrDterSAhVLLI8KHY3XCSoQFggbMAA\&url= http $\% 3 \mathrm{~A} \% 2 \mathrm{~F} \% 2 \mathrm{Flibrary}$.telkomuniversity.ac.id\%2Fp ustaka $\% 2$ Ffiles\%2F101967\%2Fjurnal eproc\%2Fanali sis-user-interface-pada-mobile-device-menggunakanheuristics-of-responsive-webdesign.pdf. [15 Maret 2017].

[5] Knight, K. (2009). Fixed vs. Fluid vs. Elastic Layout : What's The Right One For You,[online],(http://www.smashingmagazine.com/200 9/06/02/fixed-vs-fluid-vs-elastic-layout-whats-theright-onefor-you/, [15 Maret 2017].

[6] Kotaru, V.K. 2016. Material Design Implementation with AngularJS. Mumbai: Hyderabad

[7] Lestari, D.M, et al. 2014, "Analysis of User Experience Quality on Responsive Web Design from its Informative
Perspective". International Journal of Software Engineering and Its Applications.8(5),110.http://dx.doi.org/.[15 Maret 2017].

[8] Meimaharani, R and Diana Laily. 2014 "Perancangan E-Commerce Goody Bag Spunbond Menggunakan QR Code Berbasis Web Responsif'. Prosiding SNATIF.1-10. http://jurnal.umk.ac.id/.[15 Maret 2017]

[9] Natasa Subic, et al. 2014, "Responsive web design - Are we ready for the new age?". Online Journal of Applied Knowledge Management.2(1),1-11.http://www.iiakm.org /.[15 Maret 2017]

[10] Prabhu A and Shenoy, A. 2016 Introducing Materialize. Mumbai: Maharashtra.

[11] Solichin, A. 2013. Pemrograman Web dengan $P H P$ dan MySQL. Jakarta: Penerbit Universitas Budi Luhur

[12] Singh, N, et al. 2015, "Responsive Website a Transformation in Web Designing". International Journal of Engineering Technology Management and Applied Sciences. http://www.ijetmas.com/ 15 Maret 2017].

[13] Syachbana and zulkarnain akib. 2014, "perancangan website menggunakan responsive web design".Jurnal Sigmata,2(1),1-8.https:/jsi..cs.ui.ac.id.[15 Maret 2017]

[14] Waryono, A.S. 2011. Website Super Canggih dengan Plugin jQuery Terbaik. Jakarta: Mediakita

[15] Zakir, A. 2016. "Rancang Bangun Responsive Web Layout Dengan Menggunakan Bootstrap Framework".Jurnal Nasional Informatika dan Teknologi Jaringan.1(1).1-4.http://jurnal.uisu.ac.id/ [15 Maret 2017]. 